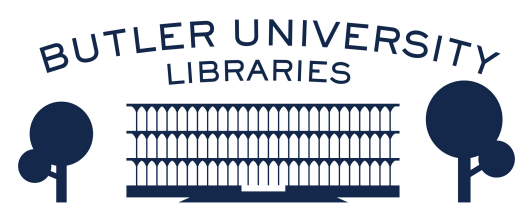

Journal of Hindu-Christian Studies

Volume 11

Article 7

January 1998

\title{
Immigrants from India in North America and Hindu-Christian Study and Dialogue
}

Raymond B. Williams

Follow this and additional works at: https://digitalcommons.butler.edu/jhcs

Part of the Religion Commons

\section{Recommended Citation}

Williams, Raymond B. (1998) "Immigrants from India in North America and Hindu-Christian Study and Dialogue," Journal of Hindu-Christian Studies: Vol. 11, Article 7.

Available at: https://doi.org/10.7825/2164-6279.1180

The Journal of Hindu-Christian Studies is a publication of the Society for Hindu-Christian Studies. The digital version is made available by Digital Commons @ Butler University. For questions about the Journal or the Society, please contact cbauman@butler.edu. For more information about Digital Commons @ Butler University, please contact digitalscholarship@butler.edu. 


\title{
Immigrants from India in North America and Hindu-Christian Study and Dialogue
}

\author{
Raymond B. Williams \\ Wabash College
}

TWO PREMISES ARE behind this essay of reflections on the experience of immigrants from India as potential participants in Hindu-Christian study and dialogue: First, potential Hindu conversation partners are no longer "over there"; rather, they are in North America. A new form of transnational Hinduism is developing that raises the question about what location (geographical and social) is best for collaborative study and dialogue to take place. Second, in the early days of establishing Hinduism in North America by immigrants, very little dialogue has taken place. Several reflections on that relative silence might provide some understanding that could provide a foundation for future conversation.

Hinduism in the United States is "Made in the USA". No Hindu group, no Hindu temple, or no Hindu program in North America is the same as in India. The million or so Hindu immigrants are creating a new form of Hinduism not found anywhere in India. The trauma of modern migration changes everything, and the process of creating and understanding what Hinduism is here - understanding by the Hindus themselves as well as their Christian neighbours - is so new that the parameters are in flux. It is as if a neighbour came over just as the moving van left to engage in discussion about the future of the neighbourhood. The new resident might say, "Please let me finish rearranging the furniture and keeping track of my children. Come back a little later."

Moreover, this newness creates potential and complexity as Hinduism becomes a "world religion" visible in the West in new ways. The more important dialogue - I won't call it interfaith dialogue - is between Hindus in America and Hindus in India regarding the shape of Hinduism in both places. Rapidity of both communication and mobility in the new immigration changes the "world view" of both immigrants and their co-religionist in India. It is increasingly the case that what happens in India has immediate impact in the United States. When a stranger knocks on the door, recent immigrants might say, "I'm sorry, but I am in the midst of a serious conversation with my brother in India. Please come back later."

These relations emerging among migrants at the close of the twentieth century generate a new transnational approach to the study of migration, which studies migrants "who develop and maintain multiple relations - familial, economic, social, organizational, religious, and political that span borders $\ldots$ and take actions, make decisions, feel concerns, and develop identities within social networks that connect them to two or more societies simultaneously". ${ }^{1}$ Immigrants with transnational relations are able to maintain several identities and to express these at times and in ways that are most advantageous to them in adapting to current circumstance and in preserving options for the future. Immigrants are inherently insecure, and uncertainties in the global economy force them to cultivate options in more than one setting. One way to do this is to use the 
wealth, social ties, and status gained in one location to develop status and capital in another. ${ }^{2}$ One result is the necessity of remapping the social and religious fields of the new immigrants to America.

\section{Immigrant Hindus}

A 1957 law prohibits the U.S. government from keeping data on religious groups, so accurate statistics regarding Hindus are not available. By now there are well over one million Asian Indians whose presence results from the Immigration Act of 1965, and a majority of these immigrants and their children are Hindus, but no one can say how many. The number is growing faster than the general population, both through new immigration, primarily for family reunification, and by natural means, because a large number of the immigrant families are in the child-bearing stage. Numerous Hindu temples and organizations appear when the children of the community reach the age to be socialized outside the home.

In another place I trace strategies of adaptation by Asian Indians: individual, national, ecumenical, ethnic, hierarchial, and denominational. ${ }^{3}$ Each of these correlates with the length of time of residence and the size of community. Yet none of these strategies of adaptation in evidence thus far includes a component of interfaith dialogue or collaborative study. It is intriguing to ponder the question: At what stage of development does/can a new immigrant community engage in such dialogue.

In the earliest period of immigration after 1965, contacts with Christians was both positive and negative. Some Hindu families sent their children to Christian Sunday Schools or Daily Vacation Bible Schools in order to provide some moral and religious education. Some nascent organizations found meeting places in church halls. On the other side, some Hindus experienced discrimination in overt acts against their meeting places, in Christian opposition to building permits for temples or cultural centres, or in sermons and/or video tapes that portrayed Hinduism as devil worship. It must be said that some Christian leaders and churches provided support for the Hindus in their attempts to establish themselves. In general, however, responses to the Hinduism of immigrants was darkened by the popular American perceptions of both the ISKCON movement and the Rajneesh episode. Indeed, immigrants debate whether it is possible for anyone to convert to Hinduism, not as a theoretical point, but as a way to alleviate the fears of settled families that new immigrants are out to convert Christian and Jewish children to Hinduism. The president of one Hindu organization told me that they had to be very careful not to appear like missionary Hinduism lest they reap the ire of Jews and Christians. Keep the head down; don't be perceived as welcoming converts; keep away from their young people. American academics (and perhaps some church leaders) have a greater fascination for missionary Hinduism - Vedanta, ISKCON, and others - than for the more important and more lasting forms of immigrant Hinduism. That raises the question of which of the forms of Hinduisms is the object of dialogue and collaborative study.

Nevertheless, it is essential for new immigrants to engage in some informal dialogue and adapt to American Christian categories. "Hello, I'm a Baptist, what are you?" is a meaningful identifying statement, because categorizing people according to religious tradition has a special meaning in the United States. The question is different, however, than one in India, "Hello, I'm a Hindu, what are you?" A young lad leading a tour of a new temple in Chicago tells the neighbours that the worship of Krishna is a form of monotheism, just like Christianity and Judaism. Or, the statement is made that Hinduism is more cultural than religious, which validates a less aggressive religious presence. Even to incorporate as a tax exempt organization in North America requires adaptation to new organizational models.

Immigrants generally form religious 
groups because of the power of religion in providing a transcendent basis for both personal and group identity, which are so important to new immigrants. Equally important, however, is to recognize that they form groups, not in order to maintain a separate existence from the settled community, but in order to negotiate from a stronger position the nature of the relationship in a newly created community.

\section{Impediments to Hindu-Christian Dialogue}

Very little formal dialogue or collaborative study has yet taken place. The questions are "Why? and "What are the impediments?" I have to confess to being an outsider looking in on Hindu-Christian dialogue, even though I am an ordained Christian. When I first went to India, an advisor told me to avoid using Christian institutions as the path to research on Hinduism, because that would make research difficult and provide a special (he thought distorting) perspective. Whether his advice was good or not, I entered the study through Hindu and university networks. Except for such private tasks as teaching a class on The Apostles' Creed to a group of sadhus in a temple in Ahmedabad or trying to explain the doctrine of the resurrection to a Hindu philosopher on an Easter Sunday during a harrowing ride in 115 degree temperature from Sarangpur to Ahmedabad (both of which help me understand the difficulty of the dialogue) or trying to live as upright a life as some of my Hindu friends (an existential form of dialogue), I have not been formally engaged in such dialogue. A number of impediments exist to participation by recent immigrants in Hindu-Christian dialogue.

(1) The tension between inclusiveness and exclusiveness is significant, and some immigrants are mystified when they come up against various forms of exclusiveness. Several shrines of Hindu immigrants contain Christian objects - a picture of Jesus, one of the Madonna, a crucifix - without any sense that a theological proposition has been transgressed. A basic difference exists regarding the theological foundations of Hindus and Christians on which dialogue is built.

(2) Local and National Councils of Churches and related interfaith agencies are enfeebled by the decline of liberal Protestant denominations and are too engrossed in survival to pay attention to immigrants, except refugees, but very few refugees are Hindu. The World Council of Churches' dialogue takes place in the marginal space totally out of the purview of immigrants. In fact, it is the case that those who are involved in interfaith dialogue are marginal people, at the edges of each tradition. The reason why academics are prominent in dialogue is not just that some academics are good at it, but because they already occupy a liminal state by the very nature of their academic calling.

(3) Some forums of religious dialogue impose older models on participants that new immigrants find strange, e.g., denomination, congregation, world religion. A Christian experience illustrates the issue. An Indian Christian bishop applied on behalf of his new diocese for membership in the National Council of Churches and was told in a form letter that he would have to show a membership of at least 10,000 persons to apply for membership. That stymied him because Indian Orthodox churches record membership by families, not individuals - a significant cultural difference. It is important to notice how the religious structures often taken for granted as a basis for dialogue are, if one can use the word, "foreign" to immigrants.

(4) The founding leaders of Hindu temples and organizations in the United States are lay people (to impose a category) who are part of the brain drain. The religious specialists arrived later as pujaris hired from major temples in India or as sadhus travelling throughout North America each summer. The lay leaders are people trained primarily in medicine, science, technology, and business. They are neither 
interested in nor competent to engage in interreligious dialogue. They are friendly and welcome sympathetic visitors, but they have difficulty explaining in detail what they do or why they do it. The specialists brought from India frequently are more proficient in an Indian language and Indian rituals than they are in English or in philosophy. A corollary to this is that these lay people often lead religious organizations in order to gain ego satisfaction that comes from exercising the leadership skills in Indian languages and modes. No such ego satisfaction currently accrues from interfaith dialogue.

(5) A basic lack of understanding of American families and religious organizations exists among immigrants. The basic social medium for Indians is family, whereas the basic social medium for Americans is friendship. That creates real tension between the immigrant generation and the second generation because the young people are caught in the middle - "You love your friends more than you love your family," parents accuse. Of course, this tension relates to marriage (which is family) and dating (which for American children is friendship). This is significant to dialogue because the immigrant generation have very few friends, if any, among the settled population - not even parents of their children's friends. Indeed, what they think they know comes from the television programs, which frightens them. They see little in American religious life to emulate or in American churches to approach. Especially when it is perceived that a danger of coming too close is to lose their children to American culture. Dialogue has to be sensitive to that dynamic.

(6) Multiculturalism, pluralism, and diversity are both code words and the emerging reality. Much scholarly work has been expended in documenting that reality. The "Protestant, Catholic, Jew" of the previous generation has now become the "Christian, Jew, Muslim". The best indications of this important transition are recent presidential statements and diverse invitees offering prayers in Congress. It has become part of American civil religion, and one might question if interfaith dialogue is simply an aspect of recreating an American civic religion. In any case, the role of Muslims in that equation is problematic for Hindus. (I think that recent estimates of the Muslim population as over 6 million are exaggerated, even though I think that the future impact of the Muslim presence is underestimated.) Nevertheless, the role of Muslims in dialogue with Christian and Jews makes the inclusion of Hindus difficult. For two reasons: (a) the coherence and exclusiveness of the Abrahamic religions mentioned earlier, and (b) the history and current state of Hindu-Muslim relations in India that colour contacts in the United States.

(7) Some political-religious changes in India have a chilling effect on relations of Hindus with others, even in the United States. Hindus moved from being part of the majority in India to that of a very small minority in the United States. The surge of the BJP as a political party in India and the growth of the Vishwa Hindu Parishad in North America, both strengthened by the Ayodhya episode, introduce a strident element into the rhetoric of some Hindus, primarily against Muslims, but rubbing off onto other groups as well. The tension is maintained by the annual visits of leaders from India and by constant communication in media, newspapers, newsletters, video tapes, etc. Financial support from the United States supports attacks on religious minorities in India. Such stridency is evidence of the need for interreligious conversation both in India and the United States. The Hindu-Christian dialogue and collaborative study in the United States must take account of these tensions within the Asian Indian community.

(8) Even though Hindus live in small towns in the United States, they travel to religious institutions that are urban. The clientele of Hindu temples is non-resident. 
People drive for many miles to visit the temple or to attend a religious function. Down on the ground, no sense of connecting with the residential communities of churches or synagogues near temples exists. Much interfaith dialogue begins with life and work rather than with faith and order, and little opportunity exists for cooperative work when participants are so scattered.

(9) New Christian immigrants from several countries have experience of living and negotiating with people of other religions - Indians with Hindus and Muslims, Koreans with Buddhists, Syrians with Muslims - but what little interfaith discussion that exists in North America takes place without taking into account the experience of these new immigrants. Some years ago Methodist women studying Hinduism in preparation for their yearly study met on the same campus in Chicago where Indian Christians were having their annual meeting. The Methodists displayed little interest in South Asian Christianity; the Indians could not understand the fascination with Hindu gods and texts. The only positive contact between the two groups was when some Methodists dressed in saris for dinner. The Indian Christian women finally said, "If you are going to wear saris, let us show you how to put them on correctly."

\section{Conclusion}

Hindu-Christian dialogue in the United States has become a trialogue of American Christians, Indian Hindus, and American Hindus, with the latter a silent partner. The immigrant community is not ready yet to participate, and probably won't be until it has created and educated its own religious specialists. In the interim, the danger is that Christian conversation partners will reify either Hinduism in India or that in the United States as somehow normative (although I recognize that is a dirty word in some contexts). The conversation has become more complex.

New immigrants change both the context and goal of interreligious dialogue. The current need for dialogue takes place amid a fundamental shift in the intellectual and religious underpinnings of American culture that involves a serious revisioning of religious public discourse and civic life in the United States. "Judeo-Christian" as a concept is the construct of earlier generations growing out of the negotiations of immigrants in the United States. That powerful construct provided a moral and religious basis for civic life and undergirded the American experiment for over a century. New immigration has made that construct relatively impotent for its civic function, and corollary forces try to kill it. One despairs of the continuation of the American experiment unless we are able to create mutual understandings and common commitments that sustain us; what Joe Kitagawa called a "realistic equilibrium of a tripartite scheme - namely, piety in religion, morality in political life, and knowledge-rationality in culture." ${ }^{4}$ It is precisely out of that despair, or its brighter side, hope for a better future, that all forms of interreligious dialogue and collaborative study flow.

\section{Notes}

1. Nina Glick Schiller, Linda Basch, and Cristina Blanc-Szanton (eds.). Towards a Transnational Perspective on Migration: Race; Class, Ethnicity, and Nationalism Reconsidered. Vol. 645. Annals of the New York Academy of Sciences. (New York: The New York Academy of Sciences. Glick Schiller, Basch, and Blanc-Szanton): pp.1-24.

2. Nina Glick Schiller, et al, Towards $a$ Transnational Perspective on Migration: Race, Class, Ethnicity, and Nationalism Reconsidered, p.112.

3. Raymond Brady Williams, Christian Pluralism in the United States: the Indian immigrant experience. (Cambridge: Cambridge University Press, 1996).

4. Joseph M. Kitagawa, The Christian Tradition: beyond its European captivity. (Philadelphia: Trinity Press International, 1992). 